\title{
Pengaruh Pemberian Valsartan Dan Kurkumin Terhadap Pembentukan Fibrosis Di Tubulus Proksimal Ginjal Akibat Obstruksi Ureter Unilateral pada Tikus Wistar.
}

Lubis $\mathrm{M}^{\star}$, Alvarino*, Tofrizal**, Erkadius***

Abstrak

Pendahuluan: Obstruksi ureter adalah kondisi terhalangnya aliran urin dari ginjal ke buli-buli, adanya obstruksi pada ureter memperlambat laju filtrasi glomerulus dan dapat menyebabkan kerusakan parenkim ginjal. Fibrosis pada ginjal yang obstruksi timbul melalui dua mediator yaitu tumor nekrotik factor (TNF- $\alpha$ ) dan angiotensin II. Penghambatan kedua mediator ini akan menurunkan tingkat fibrosis di tubulus proksimal ginjal akibat obstruksi. Zat yang bisa menghambat TNF- $\alpha$ salah satunya adalah kurkumin sedangkan Angitensin II dapat dihambat dengan valsatran. Metode: Penelitian ini merupakan penelitian eksperimental, tikus wistar dibagi dalam dua kelompok dengan jumlah tiap kelompok adalah 15 ekor. Proksimal ureter kanan diikat dan kelompok perlakuan 1 sebagai kontrol diberi valsatran, kelompok perlakuan2 diberi valsartan dan kurkumin. Pemberian oral, dimana obat dilakukan pengenceran. Hari ke lima belas dilakukan pengambilan ginjal tikus wistar, diperiksa histologi. Pembentukan fibrosis di tubulus proksimal dianalisa dengan uji statistik chisquare dengan koreksi Yates dan $t$ test, sedang terbentuknya degenerasi hidrofik dan terbentuknya atrofi pada tubulus proksimal dianalisa dengan uji statistik $t$ test. Hasil: Adanya perbedaan bermakna perubahan pembentukan fibrosis di tubulus proksimal ginjal antara kelompok perlakuan dan kontrol ( Chi Squqre didapat nilai $\mathrm{p}$ $\leq 0,001$ dan dengan $t$ test didapat nilai $\mathrm{p} \leq 0,000$ ). Terbentuknya degenerasi hidrofilik di tubulus proksimal ginjal terdapat perbedaan bermakna terbentuknya degenerasi hidrofilik kelompok perlakuan dan kelompok kontrol ( $\mathrm{t}$ test didapatkan nilai $\mathrm{p} \leq 0,000$ ). Terbentuknya atrofi di tubulus proksimal terdapatt perbedaan bermakna terbentuknya atrofi di tubulus proksimal ginjal kelompok perlakuan dan kelompok kontrol ( $\mathrm{t}$ test didapat nilai $\mathrm{p} \leq 0,000$ ). Kesimpulan: Ada perbedaan pengaruh pemberian valsartan dan valsartan + kurkumin terhadap pembentukan fibrosis di tubulus proksimal ginjal. Perbedaan bermakna terbentu

Kata kunci: Obstruksi ureter, Valsartan, Kurkumin, Fibrosis, Degenerasi hidrofilik, Atrofi

\begin{abstract}
Introduction: ureter obstruction is a condition where is an obstacle for urine flow from renal to blast (vesica urinaria). The obstruction in ureter will decrease glomerulus filtration flow and it destroys renal parenchym. Fibroses in obstructed renal present through two mediators, there are necrotizing tumor factors- $\alpha$ (TNF- $\alpha$ ) and angiotension-II. Obstruction of this two mediators will decrease fibroses grading in proximal tubules of renal caused by obtruction. One of TNF- $\alpha$ inhibitors is curcumene and angiotension-ll will be obstructed by valsartan. Methods: this experiment is kind of experimental type using animal experiment (Wistar Mice). Wistar Mice are divided into two groups, each group consist of 15 mice, so the total are 30 mice. This animals tighted with at proximal ureter The first group is control one, given valsartan. The second group is given valsartan and curcumene. Oral route and dilution before given. Medicine is given use 1 cc spuit. Giving action in 14 days. The fifteenth day, we take renal of Wistar and do histology examination. Significant difference between fibroses forming in proximal tubulus analyzed by Chi Square Statistic Test with correction of Yates and T-Test, beside that, hydofic degeneration and atrophy in proximal tubulus analyzed by $T$-Test Statistic Test. Result: there is significant difference in forming of fibroses in proximal tubules of renal between action group and controlled group (Chi Square with $p \leq 0.0001$ and T-Test with $p \leq 0.000$ ). In hydrophilic degeneration forming in proximal tubules gotten significant difference between two groups ( T-Test with $p \leq 0.000$ ). In atrophy forming in proximal tubules, there is important difference between two groups (T-Test with $p \leq 0.000)$. Concultion. There is an effect in giving valsartan and curcumene to fibroses forming in proximal tubules of renal. There is significant difference in hydrophilic degeneration in proximal tubules of renal. And also there is important difference in atrophy forming in proximal tubules between two groups.
\end{abstract}

Keywords:ureter obstruction, valsartan, curcumene, fibroses, hydrophilic degeneration, atrophy. 
Affiliasi penulis : *Dosen Bagian Bedah Fakultas Kedokteran Unand/RSUP. Dr. M. Djamil Padang ${ }^{\star \star}$ Dosen Bagian Patologi Anatomi Fakultas Kedokteran Unand ${ }^{* * *}$ Dosen Bagian Fisiologi Fakultas Kedokteran Unand.

Korespondensi :Bagian Bedah Fakultas Kedokteran Unand/RSUP Dr. M. Djamil Padang, mahyuzarlubis@rocketmail.com Telp: 081374835681

\section{PENDAHULUAN}

Obstruksi ureter adalah kondisi terhalangnya aliran urin dari ginjal ke buli-buli., adanya obstruksi pada ureter akan memperlambat laju filtrasi glomerulus dan dapat menyebabkan kerusakan parenkim ginjal..$^{(1,2,3,4)}$ Komplikasi lainnya adalah dari infeksi ringan dengan keluhan demam dan nyeri saja sampai infeksi berat dengan gejala sepsis. Komplikasi akhir adalah gagal ginjal terminal. Obstruksi saluran kemih merupakan kelainan yang paling sering terjadi pada masa kehamilan, anak-anak dan dewasa. Angka kejadiannya $3.1 \%$ dari 59,064 outopsi. Tidak ada perbedaan jenis kelamin sampai usia 20 tahun. ${ }^{(1,5,6)}$

Angka kejadian hidronefrosis pada bayi dan anak adalah 1\%. Obstruksi saluran kemih merupakan penyebab utama gagal ginjal terminal pada anak usia kurang satu tahun dengan angka transplantasi 23\%. ${ }^{(1,2,3,4,5,6)}$ Pada tahun 1999, di United Kingdom diperoleh data 53,4 per 1 juta anak mengalami terapi pengganti ginjal di mana $2,4 \%$ terjadi pada umur kurang dari 2 tahun, $6,4 \%$ pada umur 2-5 tahun, $20,5 \%$ pada umur $5-10$ tahun $41,2 \%$ pada umur $10-15$ tahun dan $29,5 \%$ pada umur $15-18$ tahun. ${ }^{(5,7,8)}$ Pada dewasa obstruksi ureter unilateral $1 / 1000$ orang. ${ }^{(9)}$ Gagal ginjal akibat obstruksi ureter muncul karena terjadinya fibrosis pada ginjal yang obstruksi. ${ }^{(1,2,4,5,7,8,10)}$

Fibrosis pada ginjal obstruksi timbul melalui dua mediator yaitu tumor nekrotik factor $\alpha$ dan angiotensin II. Tumor nekrotik factor a merupakan sitokin menyebabkan inflamasi yang diproduksi oleh makrofag, dan sel-sel epitel ginjal mesangial dan tubular. $^{(1,7)}$ Pada ginjal diproduksi oleh sel ginjal intrinsik, termasuk sel-sel mesangial dan sel epitel tubular, dalam menanggapi rangsangan inflamasi seperti platelet-derived growth factor (PDGF) dan tumor necrotic factor- $\alpha$ ( TNFa ). . $^{(5,6,11)}$

Angiotensin II merupakan peptida utama dari sistem renin angiotensin sebagai faktor pertumbuhan yang mengatur proliferasi sel, apoptosis, dan fibrosis. Angiotensin II sebagai mediator penyebab inflamasi yang berperan dalam respon inflamasi, di ginjal Angiotensin II dan TNF- $\alpha$ berkonstribusi menyebabkan fibrosis ginjal. Penghambatan kedua zat ini akan menurunkan tingkat kerusakan ginjal akibat obstruksi. Salah satu zat yang bisa menghambat TNF- $\alpha$ adalah kurkumin sedangkan Angiotensin II dapat dihambat dengan valsatran. ${ }^{(1,5,6,7,11,12,13)}$

Kurkumin adalah bahan aktif dalam obat herbal tradisional dari kunyit (Curcuma longa) dan sedang menjalani uji klinis untuk berbagai penyakit seperti kanker, penyakit Alzheimer's, dan kolitis ulserativa ${ }^{(11)}$. Ada kemungkinan bahwa banyak efek menguntungkan dari kurkumin berhubungan dengan kemampuannya untuk menekan peradangan akut dan kronis. Kurkumin ditunjukkan untuk menghambat TNF- $\alpha$ tergantung pada aktivasi nukleus faktor ( NF- $\beta$ ) pada sel ginjal embrio manusia. Kurkumin telah terbukti efektif dalam meningkatkan fungsi ginjal pada hewan diabetes dan gagal ginjal akut. ${ }^{(14,15,16)}$ Kurkumin dapat menurunkan resiko atherosclerosis dengan menekan TNF- $\alpha .^{(15)}$
Valsartan adalah angiotensin II reseptor blocker (ARB) bekerja sebagai relaksasi pembuluh darah dan membantu dalam menurunkan tekanan darah. Hal ini mencegah aksi hormon yang disebut angiotensin $\mathrm{II}^{(11)}$. Valsartan yang digunakan pada penelitian ini menggunakan diovan. ${ }^{(17)}$ Penelitian dilakukan Wen pyng wu dkk selama 14 hari menyimpulkan Valsartan dan aliskiren meningkatkan perlindungan ginjal terhadap fibrosis dan peradangan selama obstruksi pada tikus wistar. ${ }^{(13)}$

Bertolak dari pemikiran diatas kami tertarik untuk meneliti pengaruh pemberian valsartan dan kurkumin terhadap pembentukan fibrosis di tubulus proksimal ginjal akibat obstruksi ureter unilateral pada tikus wistar.

\section{METODE}

Penelitian ini adalah penelitian eksperimental dengan menggunakan tikus wistar dibagi dalam 2 kelompok dengan jumlah tiap kelompok adalah 15 ekor. Tikus wistar jantan umur 3 bulan, berat 150-200 gram, tidak ada cacat secara anatomi dan sehat diadaptasi selama 1 minggu, dan diberi pakan standar serta minum. Hewan dibius dengan dietil eter sebelum mereka menjalani sayatan perut pada garis tengah, ureter kanan terbuka dan diikat menggunakan Prolene 4-0 pada proksimal ureter. Perut ditutup dengan jahit mengunakan silk 3.0.

Konversi dosis manusia dengan berat badan $70 \mathrm{~kg}$ ke tikus wistar yang berat badan $200 \mathrm{gr}$ adalah 0,018, sehingga didapatkan dosis valsartan untuk tikus $/ \mathrm{kg}$ BB adalah $1,44 \mathrm{mg} / 200 \mathrm{mgBB}$ tikus dan didapat dosis kurkumin untuk tikus wistar/kb BB adalah sebanyak $5,4 \mathrm{mg} / 200 \mathrm{mgBB}$ tikus. Kelompok perlakuan 1 sebagai control diberi valsartan dan kelompok perlakuan 2 diberi valsartan dan curcumin. Pemberian melalui oral, dimana sebelumnya obat dilakukan pengenceran. Obat diberikan dengan menggunakan spuit 1cc.

Diberi perlakuan selama empat belas hari. Ginjalnya diambil, dibuat preparat histologi dengan pewarnaaan $\mathrm{HE}$, lalu dilakukan pemeriksaan mikroskopis. Dari setiap tikus wistar dibuat 2 preparat ginjal dan tiap preparat dibaca dalam 5 lapangan pandang yaitu pada keempat sudut dan bagian tengah preparat dengan pembesaran 10x dan 40x. Sasaran yang dibaca adalah gambaran struktur histologi ginjal tikus wist ar. Data pemeriksaan ditulis dalam formulir untuk kemudian dianalisis.

\section{HASIL PENELITIAN}

Dengan membuat variabel ada dan tidak ada fibrosis, nilai Chi Sq $(12,150)$ dengan koreksi Yates menunjukkan perbedaan yang bermakna $(P \leq 0,001)$ antara pemberian valsartan dan valsartan dengan kurkumin.

Tabel.1. Distribusi frekuensi pemberian perlakuan, fibrosi sekitar tubulus proksimal

\begin{tabular}{llll}
\hline $\begin{array}{l}\text { Fibrosis Sekitar } \\
\text { Tubulus Proksimal } \\
\text { Per 100 Tubuli }\end{array}$ & $\begin{array}{l}\text { Valsart } \\
\text { an }\end{array}$ & $\begin{array}{l}\text { Valsartan } \\
\text { Kurkumin }\end{array}$ & Total \\
\hline$(-)$ & & 10 & 10 \\
(+)ringan 8\% & 1 & 2 & 3 \\
(+)ringan 10\% & 1 & 3 & 4 \\
$(+)$ ringan 12\% & 3 & & 3 \\
$(+)$ ringan 15\% & 9 & & 9 \\
$(+)$ ringan 17\% & 1 & & 1 \\
\hline Total & 15 & 15 & 30 \\
\hline
\end{tabular}


Dari Uji statistik dengan t- test menunjukkan perbedaan yang bermakna pada pembentukan fibrosis dengan $P=0,000$ atau Valsartan $(13,7 \pm 2,4)$ dan Valsartan dengan Kurkumin $(3,1 \pm 1,8)$.

Tabel 2. Hubungan Perlakuan Terhadap terbentuknya degenerasi hidrofik pada tubulus proximal

\begin{tabular}{cccc}
\hline $\begin{array}{c}\text { Degradasi } \\
\text { Hidrofik } \\
\text { (dalam \%) }\end{array}$ & Valsartan & $\begin{array}{c}\text { Valsartan }+ \\
\text { Kurkumin }\end{array}$ & Total \\
\hline $1-10$ & & & \\
$11-20$ & 2 & & 2 \\
$21-30$ & 13 & 5 & 13 \\
$31-40$ & & 5 & 5 \\
$41-50$ & & 3 & 5 \\
$51-60$ & & 2 & 2 \\
$61-70$ & & & \\
$71-80$ & & & 30 \\
$81-90$ & 15 & 15 & 30 \\
$91-100$ & & & \\
\hline Total & & & \\
\hline
\end{tabular}

Dari Uji statistik dengan t- test menunjukkan perbedaan yang bermakna pada degenerasi hidrofilik dengan $P=0,000$ atau Valsartan $(33,7 \pm 1,8)$ dan Valsartan dengan Kurkumin $(57,5 \pm 8,7)$.

Tabel 3. Hubungan Perlakuan Terhadap terbentuknya atrofi pada tubulus

\begin{tabular}{cccc}
\hline $\begin{array}{c}\text { Atrofi Tubuli } \\
\text { (dalam \%) }\end{array}$ & Valsartan & $\begin{array}{c}\text { Valsartan }+ \\
\text { Kurkumin }\end{array}$ & Total \\
\hline $1-10$ & & & \\
$11-20$ & & 2 & 2 \\
$21-30$ & & 13 & 13 \\
$31-40$ & 5 & & 5 \\
$41-50$ & 5 & & 5 \\
$51-60$ & 3 & & 3 \\
$61-70$ & 2 & & 2 \\
$71-80$ & & & \\
$81-90$ & & & 30 \\
$91-100$ & & 15 & \\
\hline Total & 15 & & \\
\hline
\end{tabular}

Dari Uji statistik dengan t- test menunjukkan perbedaan yang bermakna pada atrofi tubuli dengan $\mathrm{P}$ $=0,000$ atau Valsartan $(62,1 \pm 14,3)$ dan Valsartan dengan Kurkumin $(38,7 \pm 4,3)$.

\section{Diskusi}

Fibrosis pada ginjal yang obstruksi timbul dari hari ke 7 sampai hari ke14, melalui mediator TNF- $\alpha$ an Angiotensin II. TNF- $\alpha$ menyebabkan inflamasi di sel epitel ginjal mesangial dan tubular. Angiotensin II juga menyebabkan inflamasi di tubulus. Penghambat kedua mediator diatas maka menurunkan tingkat kerusakan pada ginjal. ${ }^{(1,5,7,11)}$ Mediator penghambat TNF- $\alpha$ salah satunya kurkumin. ${ }^{(14,15)}$ Salah satu mediator yang menghambat terbentuknya angiotensin II adalah valsartan. ${ }^{(13)}$ Penggabungkan valsartan dan kurkumin diharapkan terbentuk fibrosis lebih baik. ${ }^{(1,2)}$

Dari hasil terbentuknya fibrosis secara mikroskopik yang diberikan valsartan terdapat adanya fibrosis ringan sedangkan yang diberikan valsartan dengan kurkumin tidak terbentuknya fibrosis ada 10 sampel dan fibrosis ringan 5 sampel. Dengan membuat variabel ada dan tidak ada fibrosis, nilai Chi Sq $(12,150)$ dengan koreksi Yates menunjukkan perbedaan yang bermakna $(P \leq 0,001)$ antara pemberian valsartan dan valsartan dengan kurkumin. Uji statistik lebih lanjut dengan t- test menunjukkan perbedaan yang bermakna pada pembentukan fibrosis dengan $P=0,000$ atau valsartan $(13,7 \pm 2,4)$ dan valsartan dengan kurkumin $(3,1 \pm 1,8)$.

Percobaan yang dilakukan pada tikus wistar terbentuknya degradasi hidrofilik lebih baik pada binatang percobaan dengan pemberian valsartan dengan kurkumin.Dari Uji statistik lebih lanjut dengan t- test menunjukkan perbedaan yang bermakna pada degenerasi hidrofilik dengan $P=0,000$ atau Valsartan ( $33,7 \pm 1,8)$ dan Valsartan dengan Kurkumin (57,5 $\pm 8,7)$.

Percobaan yang dilakuan pada tikus wistar terbentuknya atrofi tubuli lebih banyak pada binatang percobaan dengan pemberian valsartan dari pada yang diberikan valsartan dengan kurkumin. Dari Uji statistik lebih lanjut dengan t- test menunjukkan perbedaan yang bermakna pada atrofi tubuli dengan $P$ $=0,000$ atau Valsartan $(62,1 \pm 14,3)$ dan Valsartan dengan Kurkumin $(38,7 \pm 4,3)$.

Dari percobaan yang dilakukan pada tikus wistar maka didapatkan pemberian valsartan dengan kurkumin lebih baik dalam mengurangi tingkat fibrosis, pembentukan degradasi dan mengurangi atrofi dibandingkan dengan diberikan valsartan saja. Ini sesuai dengan teori dimana valsartan menghambat terbentuknya angiotensin II dan kurkumin menghambat terbentuknya TNF- $\alpha$.

\section{KESIMPULAN}

1. Didapatkan bahwa penggunaan valsartan dan kurkumin mengurangi tingkat fibrosis di tubulus proksimal.

2. Diidapatkan perbedaan yang bermakna dalam pembentukan fibrisis antara kedua kelompok.

3. Didapatkan perbedaan yang bermakna dalam pembentukan degenerasi hidrofilik antara kedua kelompok.

4. Didapatkan perbedaan yang bermakna dalam pembentukan atrofi antara kedua kelompok.

\section{SARAN}

1. Kurkumin dapat dipertimbangkan sebagai suplemen pada obstruksi ureter yang di terapi konservatif.

2. Perlu dilakukan penelitian lebih lanjut untuk membuktikan secara molekuler efek kurkumin terhadap kadar dan ekspresi TNF-a.

\section{Daftar Pustaka}

1. Tanagho E.A. Urinary Obstruction and Statis in Smith's General Urologi 16th ed. Appleton and Lange ; 2004.

2. Tanagho E.A. Anatomy of Genitourinary Trac in Smith's 16th ed, Appleton and Lange ; 2004.

3. Mark C.A. Surgical Anatomy of Kidney and Ureters. Dalam Wein A.J,Kavoussu L.R, Novick N.C, Partin A.W, Peters C.A editor. Campbell's Urology 7th ed, WB Saunders Company 1998.

4. Mark C.A . Pathophysiology of Urinary Trac Obstruction. Dalam Wein A.J,Kavoussu L.R, Novick N.C, Partin A.W, Peters C.A editor. Campbell's Urology 7th ed , WB Saunders Company 1998. 
5. Gillenwater Y. Obstruction Uropath. Dalam Gillenwater Y, Grayhack S.T,Howard S.S, Mitchell M.E . Adult and Pediatric Urologi vol 2, Lippincott Williams \& Wilkins 2002.

6. Rigden SPA. The management of chronic and end stage renal failure in children. Webb N.P, Robert $S$, editor. Clinical Paediatric Nephrology 3rd ed. Oxford University Press Inc, 2003.

7. Robert W.S, Urinary Fract Obstruction . Dalam Robert W.S, Kaulo K, ediotr. Disease of the Kidney \& Urinary Trac , $8^{\text {th }}$ ed vol I , Lippincott Williams \& Wilkins 2006.

8. Arvin KB. Patogenesis Kerusakan Fungsi Ginjal Akibat Obstriksi. Dalam Adelman D, Solhug J, editor. Nelson IImu Kesehatan Anak, 15th ed vol3, EGC Jakarta. 1999.

9. Congenital Obstruction Urologi: Its origin and constribution to end stage renal diseasein children Diakses dari http://www.ncbi.nlm.nih.gov/pubmed/ 11533916

10. Macfarlane. Obstruction Uropathy.Dalam Wieder S.A, editor Urologi $4^{\text {th }}$ ed, Lippincott Williams \& Wilkins 2006.
11. Gilman \& Goodman, editor.Renin dan Angiotensin, Dasar Farmakologi terapi vol 1,ed 10, EGC Jakarta. 1999.

12. Wu Pyng,Chang Hao Chi,Tsung Yang, A reduction of unilateral induced renal fibrosis by a therapy combining valsartan with alikren in American Journal of Physiology renal Physiology diakses dari http//ajrenal.physiology.org.

13. Antibody blockade of TNF-a reduces inflammation and scarring in experimental cresceutic glomerulonephritis. Diakses dari http://www.nature. com/ki/ Journal/v67

14. Angiotensin II (125) euro angiotensin.Diakses dari http://www. eurodiagnostica.com /pdf/lap

15. Anti inflammatory properties of curcumin a major constituent of curcumin: A review of preclinical and clinical research. Diakses dari http://www.thome. com

16. Synthesis of curcumin analoques biconjugats as potential anti tumor agen inisolated human sel. Diakses dari http://www.ksu edu sa/12477/ masterthesis

17. Diovan(valsatran) drug information, description, user review.Diakses dari http://www.Rxlist.com/ diovan drug.htm 